\title{
Iran-US relations; The Middle East issues
}

\author{
Samin Ustiashvili \\ , Department of American Studies \\ The International Black Sea University \\ Tbilisi 2 01031- David Aghmashenebeli Alley \\ Republic of Georgia
}

\begin{abstract}
Iran-US relations have historically been of particular importance to both sides. The ups and downs of this relationship and its causes and factors have always been considered by international relations researchers and thinkers, including the two countries' experts. This article aims to examine Israel's role in perpetuating the strained relations between Iran and the United States. The continuing turmoil and the severance of official relations between Iran and the United States, given the historical background of relations between the two countries, the existence of shared regional interests, along with the opportunities to repair and improve relations, raises the question of international relations researchers why relations between the two countries are still strained as Iran enters the fourth decade of its revolution. What are the leading causes and factors of the continuation of the strained relations between the two countries? In response to various hypotheses, the author cites a drastic change in the foreign policy of the Islamic Republic of Iran towards Israel - compared to the pre-revolutionary period - the main factor in the continuation of hostility between the two countries and Iran's opposition to Israel. Therefore, considering the opposition to the Middle East peace process as the main factor of the current situation, it has tried to confirm the mentioned hypothesis by presenting evidence and analyzing documents. This article has been written with a genealogical (historicalanalytical) approach and has a review nature. To attain the specifications of this research, a descriptive methodology has been used. The advantages presented by this method include enabling the collection of a significant amount of data at once. The scientific findings of this study indicate the undeniable effect of the Israeli variable on Iran-US relations.
\end{abstract}

Keywords: Iran, US, Israel, Middle East Peace, Strategic Relations

\section{Introduction}

Iran-US relations before the Islamic Revolution were friendly and strategic. In the Persian Gulf gendarme and US ally role, Iran had a special place in the Nixon-Kissinger two-pillar doctrine in its region. But the victory of the Islamic Revolution was an earthquake that destroyed the foundations of relations between the two countries. The Iranian government went from being America's first secret ally to its number one enemy in the Middle East. In the seizure of the embassy and the hostage-taking of American diplomats by Iranian students, and the severance of US relations with Iran, relations between the two countries have become increasingly strained, and a wall of mistrust has grown. During Hassan Rohani's government, both countries could reach the JCPOA agreement, one of the most critical challenges in their relations. However, the wall of mistrust between the two countries still remains strong. Therefore, it is still necessary to identify the components affecting the relations between the two countries and examine their role and weight to continue the current situation. The general division of the challenging areas in the relations between the two countries can be divided into four main categories (Mimiko, Oluwafemi, 2012:47):
A) Terrorism;
F) Human rights;
C) Nuclear technology; 
D) The issue of Israel and the Middle East peace process.

The focal point of this article is the effect of Iran's opposition to Israel and the Middle East peace process on the continuation of the strained relations between Iran and the United States. For this purpose, with a brief reference to the theoretical foundations of the two governments, first, the developments in Iran-Israel relations during the Monarchy period of Mohammad Reza Pahlavi will be analyzed, and then during the Islamic Republic. Second, the importance of the Middle East to the United States and Israel's position will be examined. Finally, focusing on the center of gravity of US Middle East policies, Iran's position toward Israel, and, consequently, the Middle East peace process and its impact on the relations with the United States will be perused.

\section{Theoretical Foundations}

The theoretical foundations of the Israeli government can be better explained by applying the theory of aggressive neo-realism since the performance of this government indicates the changing dominance of security over identity in foreign policy. According to this theory, security is the priority of governments. Every government should always strive to increase its offensive power and provide and guarantee national security by taking preventive measures against potential and actual enemies and stand against any violence by rivals and enemies (Mearsheimer, 2013:77).

From this point of view, security is the only element, motivation, and stimulus that determines the behavior of governments in the international arena (Souva,2005:151). According to Kenneth Waltz, governments are key players in international relations, and anarchy dominates international relations. As a result, Governments that act rationally are forced to help themselves and protect themselves in the face of internal and external threats. In Waltz's view, war can happen at any moment, so governments must always be ready to fight (Waltz, 1979:102). Security for survival is the primary goal of governments' foreign behavior and policies (Griffiths,2007:13).

However, the international behavior and action of the Islamic Republic indicate the precedence of the identity component over other components and a constructivist view (Alexander Wendt; 1992: 391-425), and the constructivist theory offers a more convincing explanation for the foreign behavior of the Islamic Republic. According to this view, values and beliefs shape identity, and the essence of each state determines the role which is guiding the foreign behavior of that state. Identity is a phenomenon and a concept formed and manifested in the relationship between oneself and another. It is not a phenomenon that has already been given and taken for granted. Still, it is created in the process of interaction and affects the interests and priorities of individuals and governments. Wendt considers identity to be in the interest of goods, but he believes it cannot be reduced to that. He points to four types of identity, all of which are reflected in foreign policy behavior; in addition, he pays attention to both objective and subjective interests and considers objective interests necessary to reproduce identity (Wendt 1992: 229-338). Therefore, the Islamic Republic with the Islamic suffix has given itself a role that requires the protection of Islamic values and, consequently, Islamic movements and Muslims. Meanwhile, the support for Palestine and its opposition to Israel has become an integral part of the Islamic Republic's identity. Therefore, considering Iran's support to Palestinian militant groups and Hezbollah in Lebanon, its opposition to the Middle East peace process, its missile industry development, and nuclear technology, it is understandable that Israel sees a direct threat to its existence.

\section{Historical relation between Iran and Israel}

Iran-Israel relations have been a sensitive and controversial issue in Iran's foreign policy since the creation of this regime in 1948. The different types of relations and associations between the two countries during the Shah and the Islamic Republic of Iran did not reduce the issue's sensitivity, and this perception is still high.

The Shah's regime recognized Israel in 1949 as de facto. This recognition was withdrawn during the administration of Dr. Mohammad Mossadiegh, the democratically elected Prime Minister. Still, with the fall of Mossadegh's government and the consolidation of the foundations of Mohammad Reza Pahlavi's reign after the coup d'état of 23 July, relations between the two countries were resumed in 1959. It was established under "Bern 2" in Switzerland and lasted until the end of the Shah's fall in February 1978 (Milani: 2013: 284; Velayati 2001: 27-30).

Relations between the two countries during the mentioned period in the political, security, economic and military fields expanded rapidly. At the end of the Pahlavi regime, we can talk about the strategic but often 
secret relations between the two countries. Numerous national, regional, and international factors were involved and influential in expanding and strengthening these relations. On the one hand, Iran and Israel were considered the only non-Arab countries in the Middle East. On the other hand, the Shah's doctrine of positive nationalism based on the pursuit of national interests with religious tolerance in foreign relations was in harmony and concord (Cooley, 2005:81; Fallahi Nejad 2002: 121-127).

This variable, along with other bilateral variables such as Israel's vital need for oil (due to Arab sanctions), the Iranian market, and Israel's economic, technological and security ${ }^{1}$, attractions as the most advanced country in the region from the Shah's point of view, played a significant role in developing bilateral relations (Velayati 2001: 180-201) (Information of the IRGC Joint Staff 1999) ( Halidi 1979: 228).

At the regional level, the two countries' fear of radical Arab regimes was another factor in the convergence and intelligence cooperation between Mossad and SAVAK (Parsi 1991: 182-185; Iam 2007:29). At the international level, the belonging of both countries to the Western camp and confrontation with the Soviet Union were other reasons for strengthening relations between them. However, despite the depth of relations between the two countries, the Shah considered the public opinion of the Arab countries and the Iranian population, and until the end of its rule, he refused to recognize Israel as an independent state formally (de Jure).

Nevertheless, with the victory of the Islamic Revolution, the agents of convergence gave way to the agents of divergence, and the Israeli embassy became the embassy of Palestine. And not only did Israel lost its main regional ally, but its first-rate ally also became the number one enemy of that government. It was not long before opposition to Israel became an integral part of the identity of the Islamic Republic of Iran and became a constant axis of Iran's foreign policy.

Israeli leaders call for global confrontation over Islamic Republic declaration policies to destroy Israel (Zohar, 2014:2). Israeli officials have repeatedly and explicitly considered the Islamic Republic of Iran as their most significant security threat since the revolution. Among them Shimon Peres, who believes that "Israel is not threatened by any country except Iran and that this government is the biggest threat to Israel's security and existence." Yitzhak Rabin commented that" in case of any war, Israel's biggest threat would be only Iran" (Jafari Valdani, 2003: 83-83).

Most of the Israeli officials' maneuver in threatening Iran for Israel's existence is focused on Iran's support for Lebanon's Hezbollah and the development of the missile industry. Regarding the Islamic Republic's explicit support for Hezbollah in Lebanon ${ }^{2}$, it is argued that by supporting Hezbollah, Iran has, first of all, a weapon of action against Israel. Second, it expands its influence beyond its borders; and third, in some cases, it uses Hezbollah to eliminate dissidents and harm US interests in the region (Byman, 2002:61).

Iran's missile industry is another Israeli security concern. The development of the Islamic Republic's longrange ballistic missile capabilities and their test launch, along with the engraving of slogans in English depicting the destruction of Israel and the United States - on their surface (Camp 2002:59), prompted Ariel Sharon to react. In an interview with the Maariv newspaper, he called Iran a significant problem for Israel. He claimed that Iran was taking crucial steps to develop weapons of mass destruction and that the Shahab missiles were a severe threat to Israel (Abdollahi and Zibaii, 2002:596). The relationship between the Islamic Republic and Hezbollah in Lebanon and the comprehensive development of missile technology and March 2016 tests are still the pretext for Israel to introduce the Islamic Republic as a threat to world peace and security (Haaretz, April 10, 2016).

The situation in the picture continues, and there is no sign of the end of the propaganda war, rhetoric, and threats between those two governments.

\section{America and the Middle East}

The Middle East is also strategically important, as it lies between Europe, Africa, and Asia, and the Straits of Hormuz (Which connects the Persian Gulf to the Oman Sea and the Indian Ocean) and Bab al-Mandeb (which connects the Red Sea to the Indian Ocean) as well as the Suez Canal (which connects the Red Sea to the Mediterranean). It is economically remarkable since it has the most well-known oil and gas reserves and

\footnotetext{
${ }^{1}$ Samuel Segev The Iranian Triangle The Untold story of Israel 's Role in The Iran Contra Affair. The Free Press A Division of Macmilan,. INE New York. 1988

${ }^{2}$ Ayatollah Khamenei declares support for Lebanese Hezbollah obligatory for all Islamic communities. (July 23, 2006) and Ali Larijani, then secretary of the Supreme National Security Council of the Islamic Republic of Iran, also considered Hezbollah to be part of the Iranian population. (July 23, 2006)
} 
thirsty markets for manufactured goods. Therefore, regional and supra-regional powers have paid particular attention to this region throughout history and have undergone notable changes and developments. Today, the United States of America has emerged as an unrivaled superpower. Domination of the region is one of the strategic principles of this country's foreign policy due to its unique military-strategic and economic benefits.

Obviously, domination of the region is one of the strategic principles of this country's foreign policy due to its unique military-strategic and economic benefits.

In the official report ${ }^{3}$, US interests in the Middle East are categorized into three levels as follows:

1. Vital national interests;

2. Important National interests;

3. National interests.

And in each category, the interests are mentioned and examined in order of priority. The vital national interests of the United States in the Middle East are as follows:

a) Survival of Israel;

b) Ensuring the continuation of oil flow to the free market;

c) Preventing the governments of the region from acquiring weapons of mass destruction

In the Vital National Interests, the continuation and success of the Arab-Israeli peace process are mentioned in the second paragraph (Nassiri 2003: 260-264).

Graham E. Fuller, a political analyst, ranks the interests of the United States in the Middle East in the following order of importance:

a-Protection of energy resources and its continuity to the West;

b-The US continued support for Israel's security, survival, and prosperity;

c-Assist friendly governments in ensuring and strengthening the overall stability of the region;

d- US access to regional markets and maintaining continuity and influence (Fuller, 1990:419)

Sandy Berger, the former National Security Advisor of the United States, also links the U.S. interests, Israel's presence to Middle East strategic position, and commented: The Middle East is a haven for Israel, one of our closest allies... Moreover, the Middle East is home to two-thirds of the world's oil reserves, making it a vital region (Younesian 2001:5). Although this is not the issue of nowadays, as Eric Watkins argues, for the past 50 years, American policy in the Middle East has always been based on two pillars: Ensuring oil supply for the American industries;

- Establishing Israel and maintaining its security (Watkins 1997:136)

- Richard Nixon saw oil and Israel as primary U.S. interests in the Middle East, as well (Nixon 1992:266).

In the George W. Bush administration, these policies, like previous administrations, have been at the forefront of U.S. Middle East policy. A report by the Presidential Study Group on U.S. Middle East Policy advised President Bush to sustained American interests in the Middle East, including preventing war and establishing a lasting and comprehensive peace between the Arabs and Israel, ensuring security and maintaining Israel's existence... and the continuation of the supply of oil at reasonable rates (U.S. Presidential Studies Group, 2001:11). The American historian Paul Johnson beautifully stated, " The guilt of Western anti-Semitism and the oil demand committed the United States to Israel and the protection of oil reserves in the Middle East, and these two commitments formed the basis of U.S. foreign policy in the Middle East" (Heather, 1994:65).

Based on the above, it can be concluded that the main policies of the United States in the Middle East are based on two principal pillars:

1. Ensuring continued oil flow from the Middle East to the West;

2. Ensuring the security existence of Israel

\footnotetext{
${ }^{3}$ The report has been produced by 23 professors of political science and international relations with the support of Harvard University, the Robes Institute, the Nixon Center, and the Belfer Center for Scientific Research and International Affairs, under the direction of Graham T. Allison and Robert Blackwell.
} 
And other U.S. policies, such as counterterrorism, fundamentalism, weapons of mass destruction, and human rights in the region, aim to secure and consolidate the two policies.

As for the growing importance of the first pillar in the Bush administration's policies, it should be noted that there were severe oil and gas shortages in many U.S. states during the Bush presidency. Some states, such as California, were hit by power outages. For the first time in U.S. history, oil imports reached more than 50 percent of consumption and raised serious concerns about the long-term security of the energy supply (Clair, 2004:14). As a result, the Bush Administration formed the National Energy Policy Development Group (NEPDS) to develop a long-term plan to meet the U.S. energy needs. The group's final report was presented to Bush in May 2001, stating that the United States faced its most severe energy shortage in 2001 since the Arab oil embargo of the 1970s (Raeisi Toussi 2003:51). Chapter 8 of this report, entitled Strengthening Global Coalitions, shows that dependence on imported oil increased sharply. One-third of all the recommendations in this report were on ways to access foreign oil resources.

The United States is the wealthiest known energy source globally. With declining domestic oil production and increasing consumption, it is facing a growing dependence on imported oil; the Middle East region, meanwhile, is also known as the richest source of energy in the world. The countries of the Persian Gulf region have the capacity to produce additional oil equal to $91 \%$ of the total capacity of the world. In case of disruption of oil supply in other parts of the world, the use of this capacity in the Persian Gulf will compensate for the interruption. The opposite will not be accurate in the current situation (http://www.eia.gov).

If we add to the issues mentioned above and consider the International Energy Agency (IEA) report on accelerating the absolute growth of global oil demand (AmirAhmadi 2003:80), the importance of the Middle East region will increase a hundredfold. Therefore, the world economic powers, led by the United States, will react strongly to the developments in the area since their financial security and, in the case of the United States, its vital interests are intertwined with the issue of energy. The United States, as the world's largest importer of oil and the world's largest economy, views the Middle East from a crucial and strategic perspective. Washington's main and strategic priorities are to change the political structure of the Middle East, exercise control over oil flow, and intensifying pressure on its regional and transregional rivals.

Nevertheless, the second pillar of U.S. Middle East policy, which ensures Israel's security and existence, has always been at the top of U.S. goals in the region.

U.S. Special Support for Israel in Political, Military, and Economic Dimensions has Many Reasons and deep roots. But what this study seeks is the importance of Israel as a reliable and trustworthy base for the United States in the Middle East and the strategic bottleneck of global energy, which, according to Mahmoud AlSahli, has served as a bayonet to achieve U.S. goals and interests in the Middle East (Mahmood Al-Sahli, 2003:12). In addition, Noam Chomsky believes that US-Israeli relations and Israel's particular position among U.S. strategic allies above all depend on the unique role that Israel has played in shaping Americans' perceptions of their own interests in the Middle East (Chomsky 1990:36).

Continuing his outspoken support for Israel, Bush said at a news conference in April 2004: " If Iran is equipped with a nuclear weapon, the Middle East and Israel will be in grave danger, and if that happens, the United States will step in and take that opportunity from Iran... any force that opposes Israeli security will face a severe blow from the United States (Tavana 2003:5). The positions of all U.S. government officials are in line with the recommendations of the U.S. Presidential Study Group advising the then-President George Bush: "In the case of Israel, the United States must act in such a way that the Middle East countries understand the U.S. sensitivity to Israel's security, and the United States ensures that the Middle East countries have no doubts about the strength, importance and continued strategic cooperation of the United States and Israel, and realize that the United States is committed to increasing Israel's deterrent power and providing political, military, and financial support to that country"(U.S. Presidential Study Group 2001:4248).

Although Barack Obama won with the slogan of change, a radical change in US-Israeli relations would have undoubtedly been strange given the structure of the U.S. government. During the nuclear talks, whenever there was a sign of an agreement between Iran and the United States, we witnessed a protest from the Israeli officials. Jewish lobbies were among the most active opponents of the West's nuclear deal with Iran. On the eve of the nuclear agreement, P.M Netanyahu criticized the West for pursuing a nuclear deal with the Islamic Republic at any cost. He emphasized that Israel is committed to preventing Iran from acquiring a nuclear weapon (Haaretz, April 10, 2016). Famous Canadian journalist Shahir Shahidsaless believed that 
Israel's policies were a significant obstacle to a nuclear deal and that a peaceful solution was in serious jeopardy (Shahir Shahidsaless, 2013). Israel's influence on U.S. foreign policy is such that in some cases, Obama hid talks with Iran from Netanyahu to prevent Israel from disrupting the negotiations (BBC Persian, 31/3/2016), and Israeli officials saw Obama's secrecy as a U.S. dagger to his longtime ally, Israel ( Zuckerman, 2015). At any negotiation stage, the Americans sought to satisfy and persuade Israel to write a draft agreement (BBC Persian, 31/03/2016).

The recognition of Jerusalem as the capital of Israel in 2017 by President Trump and the settlement of the American Embassy from Tel Aviv to Jerusalem in 2018 signaled clearly the United States' position during that Administration to the whole world, especially Arab countries. The United States 'unwavering support for Israel and the two countries' unparalleled ties have many other reasons and align strategic interests. However, in search of the roots of the deep bond between the two countries and the entanglement of their national and vital interests, we can mention the common issues of belief and religious interests. The profound influence of Jewish traditions on American society dates back to the early days of the American Revolution of Independence. When the leaders of the Puritan denomination declared at the beginning of the American Revolution that we Americans are a chosen and unique people, we are the Israel of our day. People like Thomas Jefferson and Benjamin Franklin have proposed to portray Jewish historical experiences in the Pharaonic era, such as crossing the Red Sea to create identity and ideals and choose it as the seal of Congress, or Wilson, who believed that the ancient Jewish nation provided a model for America ( Saeidi Nejad, 2001:172). One of the main reasons for the American community's attachment to Jews is Judaism and Judaism-Christian communion, especially since the Protestant and Puritan Christian movements believe that three events must take place before the return of Christ:

the first is the formation of Greater Israel, the second is the transformation of Jerusalem into the capital of Israel, and the third is the construction of the Temple of Solomon on the ruins of Al-Aqsa Mosque (Regional Studies, 2001: 222). The human-emotional issues arising from the tragedies of World War II, the support of the Christian right and neoconservatives due to common socio-religious interests (Thomas, 2007: 174-192), common socio-political values, and belonging to a single type of political system, geopolitical and strategic considerations (Cortis: 160), and most importantly, increase the influence of Jewish lobbies, particularly AIPAC, can be other reasons of the American support to Israel. Ariel Sharon once stated (before falling into a coma): " Whenever we make a decision, many of you addressed me and said that the United States would do this and that. I want to make it clear that you must not be afraid of American pressure on Israel because we are the ones controlling the United States. And the Americans themselves are well aware of this" (Abdollah Khani, 2003: 215-216). The U.S. support and ensuring the complete security of Israel is not strange, and it even gives us a better understanding of its approach to the Middle East:

- Ratification of the Nuclear Non-Proliferation Treaty by the Middle East;

- Ratification of the Treaty on the Prohibition of the Proliferation of Chemical Weapons by Middle Eastern Countries;

- Purchase of new long-range missile deterrence as well as air defense equipment by Middle Eastern countries (Abdollah Khani, 2003: 165)

However, U.S. policy to ensure Israel's security is based on equipping the country with nuclear weapons, as John Bolton explicitly stated:

Washington is reluctant to blame Israel for nuclear proliferation because it has never been a threat to the United States (Torbati, 2003:15).

According to Seymour Myron Hersh, this policy is not empathetic negligence but a clever policy of ignoring the facts (Findley 1999:142).

The United States is committed to Israel's security and existence policy requirements, and that commitment includes economic, military, and political dimensions. The grants and concessions granted in these dimensions are so generous that they astonish observers and writers in the field of foreign policy. For example, in 1985, the Reagan administration converted Israeli loans into grants and, under a treaty, opened U.S. markets to Israeli goods without charge (Findley, 1999: 119\& 239).

The U.S. generosity in military-strategic matters is even more remarkable. In 1986, Israel was allowed to participate in a strategic defense program called Star Wars. In the process of cooperation the following year, it was recognized as a non-NATO ally of the United States ( Bard, 2007:226).

Strategic cooperation between the two countries shows that this cooperation is becoming stronger every day and covers more sensitive areas. For instance, Israel is currently connected to the U.S. satellite warning 
system, and there is a hotline as a secure computer link between the Pentagon and the Israeli Ministry of Defense (Abdollah Khani, 2003,:227); which means, according to the U.S. government, there is no line between U.S. and Israeli security.

In proportion to the documents, Israel's oil and security are central to U.S. Middle East policy. However, Middle Eastern oil is often the property of Arab states who see Israel as their enemy and have a history of bloody wars with that state. Hence, the U.S. goals of controlling the oil flow in the region and maintaining Israel's security are inherently conflicting. Nevertheless, the United States considers the fundamental solution to the conflict to establish Arab-Israeli peace. Therefore, it will do its utmost to resolve Israeli security and ensure the continued export of energy to the Middle East. Consequently, it can be said that establishing peace between the Arabs and Israel is the focus of U.S. Middle East policy in the region, which was partially successful during President Trumps' Administration with UAE and Bahrain starting a fully normalized relation with Israel.

\section{Middle East peace process and the positions of the Islamic Republic of Iran}

The Arab-Israeli peace process began with the Camp David Peace Agreement between Egypt and Israel in 1979 and continues to this day with ups and downs and various agreements. However, as the provisions of the peace agreements have not been implemented so far and several meetings have not resulted in tangible results, this process does not have a clear future due to its high complexity.

Since its establishment, the Islamic Republic of Iran has considered protecting the Palestinian people as one of the ideals and foreign policies. Accordingly, throughout its forty years of existence, the Islamic Republic has continued to provide material and spiritual support to the Palestinian people and government. In this regard, it has opposed any peace that it deems to disregard the interests of the Palestinian people at any stage. Imam Khomeini denounced the accord of Camp David and said: I do not support the plan for the independence of Israel, and its recognition by Muslims would be catastrophic, and I consider opposition to it a tremendous Islamic duty ( Noor Journal. Cover 16: 293-294). The framework of the foreign policy of the Islamic Republic of Iran regarding the Arab-Israeli conflict is based on opposition to any plan to reconcile and recognize Israel. Ayatollah Khamenei also describes the Middle East peace process as a humiliation. In our opinion, what is called the Middle East peace process is not peace but a process of betrayal and a humiliating compromise. It is up to the Muslims to oppose the Zionist enemy and the usurper of the Palestinian land in any way possible. We oppose what is called the Middle East peace dialogue because it is unjust, arrogant, humiliating, and ultimately irrational ( Soleymani 2000: 231-234).

And yet, some of the most prominent Zionists in the Middle East, such as Patrick Clawson, have always suggested that the issue of Middle East peace has become prestigious for the United States. He believes that disrupting the Middle East is an absolute strategic failure for the United States. He believes that: "Tehran has dealt a decisive strategic defeat to the United States in this regard (disrupting the competent process in the Middle East) because, apart from the issue of the peace process, few of these issues are related to the credibility of the United States, if Tehran continues to undermine the peace process, it should expect U.S. hostility toward it (Clawson 1999:22).

With the coming to power of Seyyed Mohammad Khatami, the strategy of the Islamic Republic changed somewhat, and Khatami announced in a message to U.S. President Bill Clinton that Iran would no longer support Islamic groups opposed to the Middle East peace process. He mentioned in a meeting with the Swedish Foreign Minister: "Tehran promotes peace in the Middle East and believes that all Palestinians, Jews, Muslims, and Christians, should be able to decide their own destiny without the interference of others (Nowruz newspaper, March 21, 2002). The spokesman of the Khatami government said regarding the peace draft proposed by Amir Abdullah, the previous king of Saudi Arabia that:" We approach Amir Abdullah's plan from the perspective that he has always shown over the years that he considers the interests of the Islamic world first" (Keyhan Newspaper, February 20, 2002). This position can be regarded as compared with the previous role of the Islamic Republic of Iran in opposing the Fahd peace plan. Kamal Kharrazi, Foreign Minister of Khatami's administration, said about the peace guide plan:" In this plan, various issues such as the return of refugees, Jerusalem, settlement and retreat to the 1967 borders have been postponed to the final stage of negotiations. We must wait and see what happens. If the Palestinians agree on different tendencies, we will not be hindered, and this is our national position" ( Hamshahri newspaper, July 23, 2003). Finally, following the 2003 invasion of Iraq, Iran wrote a letter to the United States offering to help to stabilize Iraq by withdrawing military support from Hamas and Hezbollah. Also, it suggested providing free 
access to its nuclear equipment. According to the report, in response to these actions, Iran had called on the United States to end its hostility toward Iran, lift all sanctions imposed on Iran, and take action to dissolve the Mojahedin Khalq Organization. However, the United States has reportedly denied the requests ( BBC Persian, January 18, 2007). Howbeit, Ahmadinejad's government returned the policies of the Islamic Republic of Iran regarding Israel to the discourse of the first decade of the Islamic Revolution. His stern stance on Israel over its demolition, holding of the International Conference of "a World without Zionism" in the first year of his presidency in Tehran, and his speech at an emergency meeting of the Organization of the Islamic Conference in Indonesia following the Israeli invasion of Lebanon in 2006 based on that" the root of all the problems in the Middle East is the rebellious, occupying and illegal Zionist regime. This regime has been forcibly imposed as a tool of aggression, threats, occupation, and division in the Islamic world. According to him, the only solution would have been the destruction and disappearance of Israel from the earth. He continued by stating, "Rice, the U.S. Secretary of States, has said the war would continue until the new Middle East would be realized," We also believe that the new East will be realized, of course, without the Zionist regime and with the presence of the state of Palestine, where Muslims, Christians, and Jews will live together in peace ( Baztab website, August 3, 2006). It marginalized the discourse and stance of the official policy of the Khatami government, which was based on accepting the results of a free referendum in occupied Palestine to achieve a just and lasting peace (Journal of foreign policy, 2006: 198). Of course, Ahmadinejad later said at the opening ceremony of the Arak Heavy Water Complex: "We are not considered a threat to any country, not even to the Zionist regime, which is our enemy in this region because we believe that a referendum is the best solution to determine its fate ( Hamshahri Newspaper, August 23, 2006). However, during the International Holocaust Conference held by the Office of International Studies of the Iranian Ministry of Foreign Affairs, he re-emphasized Israel's destruction. Again on the anniversary of the victory of the Islamic Revolution on January 21, 2007 (IRNA, January 21, 2207) and during the International Conference on "the End of Israel" on May 21, 2008 (IRNA, May 21, 2008) at the University of Tehran Indicating the continuation of the policy of opposition to Israel, the Middle East peace process and even the existence of Israel, he once again introduced the Islamic Republic of Iran as the strongest opponent of the Middle East peace process. However, with Hassan Rouhani's administration, there were signs of a return to the policy of ratification and acceptance of the Palestinian vote and opinion in determining its own destiny, until Hassan Rohani called Israel in the annual Islamic Unity Conference in 2018, a fake regime created by the Western powers and adding that it is a cancerous tumor in the Middle East.

\section{Conclusion}

As mentioned, the Middle East is of fundamental importance to the United States for two reasons; One is the issue of oil, and the other is Israel's security, which, according to U.S. security officials, is at the forefront of U.S. vital interests in the region.

Regarding the oil flow and ensuring its security and stability, the interests of Iran and the United States are not disproportionate because Iran's economic life and growth depend on the stability, security, and continuity of the oil export supply. On the other hand, given Iran's declining influence in OPEC, it seems unlikely that the Islamic Republic of Iran will be able to play a decisive role in determining OPEC's overall policies in conflict with U.S. oil interests ever. What remains is the issue of Israel and its security, in which case Iran's policy is in stark contrast to U.S. policy.

IN THIS REGARD, the U.S. strategic policy is to establish a lasting peace between all Arab states and Israel, because only then will both the long-term security of Israel be guaranteed and the U.S. would be relieved of the stability and security of the oil flow and energy to the West. In addition, in peacetime, Israel would become the region's economic, political, and military center of gravity and better safeguard the United States' interests in the Middle East. Notwithstanding, the Islamic Republic of Iran, with its strong opposition to Israel and the US-Israeli peace process, targets the U.S. Middle East policy tent. By taking a critical stance on Middle East peace, it will also hinder the cooperation and empathy of Muslim Arab countries with this process. It would also strengthen and encourage Palestinian militant groups, especially the Lebanese Hezbollah, to fight against Israel and create a permanent security crisis in Israel. One of the essential elements of the U.S. security system in the new Middle East system is to put pressure, sanctions, and restrictions on countries opposing Israel and the Middle East peace process, and Iran in particular, which is considered the flagship of opposition to the Middle East peace process. Most scholars and experts on Middle East issues and Iran-US relations (such as Jeffrey Kemp, Newsom, Brent Scowcroft, Mark 
Gaziurfsky, Noam Chomsky, James Bale) explicitly stated that Iran-US relations end with the issue of Israel. Israel is the main factor in the growing tension, hatred, and revolt between the two governments of Iran and the United States. Many experts believe that the sequence and crisis between Iran and U.S. relations go through the Israeli government's political, economic, and military interests and priorities. Fuller, a senior CIA official who has been active in the Middle East, including Iran, for many years and has always been a supporter of Israel, described the problems in relations between the two countries as following: " Any attempt to achieve a realistic and balanced analysis of the Iranian government is challenging, as there is a hotbed of pro-Israel lobbying and propaganda against Iran in Congress and the Senate, which undermines any transparency in relations between the two countries.

Trita Parsi, a Middle East expert at Johns Hopkins University, also believes: whenever the United States has shown signs of compromising with Iran, Israel has tried to return it to its former position. Therefore, it seems that the blind alley of Iran-US relations lies in the shorter alley of Iran's position towards Israel and the Middle East peace process. As long as this remains the case, neither the U.S. government (whether Democratic or Republican) nor Congress would be willing or able to change its policies toward Iran. Given the insistence of the officials of the Islamic Republic of Iran on their positions and the unchangeable reading of the strategy of the Islamic Republic of Iran on the issue of Israel and Palestine, the future horizon in the relations between Iran and the United States - despite the nuclear deal - will remain strained.

\section{References:}

1. Information Office of the Joint Staff of the Revolutionary Guards (1999), Debts of the Zionist Regime to the Islamic Republic of Iran Tehran, IRGC Publications

2. Ehteshami, Anoushirvan (1999), Iran's foreign policy during the construction period, translated by Ebrahim and Zohreh Postinchi. Tehran, Islamic Revolution Documentation Center

3. Iran's foreign policy: From Khatami to Ahmadinejad, edited by Anoushiravan Ehteshami and Mahjjoob Zweiri, Readin: Ithaca Press, 2008, ISBN 978-0-86372-324-7, xviii+ 149 pp

4. Asadollahi, Massoud (2003), Lebanese Hezbollah Movement, Past and Present, Tehran, Institute for Strategic Studies

5. Mimiko, Oluwafemi (2012). Globalization: The Politics of Global Economic Relations and International Business. Durham, N.C.: Carolina Academic. p. 47.

6. Asadian, Amir (2002), US Security Policies in the Persian Gulf, Tehran, Institute for Strategic Studies

7. O'Brien Lee, (1986), American Jewish Organization and Israel. Translated by Ali Naseri, Tehran, Noor Publications.

8. Zbigniew, Brzezinski, with Anthony Lake, F. Gregory, and III Gause (2001) The United States and the Persian Gulf, Council on Foreign Relations Press, ISBN 0-87609-291-1

9. Robert M., Gates and Zbigniew Brzezinski, Iran: Time for a New Approach, (2003) Council on Foreign Relations Press, ISBN 0-87609-345-4

10. A. Bill, James (1992) The Eagle and the Lion: The Tragedy of American-Iran Relations, published by Yale University Press

11. Jafari Valdani, Asghar ( 2003) Foreign Relations of Iran (after the Islamic Revolution), Tehran, Published by Avae Noor.

12. Chomsky Noam, (1984) Fateful Triangle: The United States, Israel, and the Palestinians Published by South End Press US; Between the Lines Books Canada

13. Khalili, Assadollah ( 2002) Iran-US Relations, Tehran, Published by Abrar Moaser Tehran

14. Khomeini, Ruhollah (1999) Sahifa Noor, vol. 16. Tehran, Imam Works Organization and Publishing Institute.

15. Soleimani Mohammad Baqir, (2000) actors in the Middle East peace process. Tehran, Office of Political and International Studies, Ministry of Foreign Affairs.

16. Abdullah Khani, (2003)The American-Israeli Book on US-Israeli Relations, Tehran, Abrar Contemporary Institute, Tehran.

17. Abdullahi, Ismail Vazibaei, Mahdi ( 2002) Strategic Estimation of Israel, Tehran, Abrar Contemporary Cultural Institute, Tehran.

18. Fallahi Ali Nejad, (2002), Iran-Israel Relations in the Second Pahlavi Period, Tehran, Islamic Revolutionary Documentation Center. 
19. Findley, Paul ( 2003), They dare to speak out: people and Institutions confront Israel's Lobby, Published by Chicago: Lawrence Hill Books

20. Findley, Paul, ( 2009), Deliberate Deception: Facing the Facts about the U.S.- Israeli Relationship, Published by Chicago: Lawrence Hill Books

21. Clawson,Patrick ( 1997)U.S. sanctions on Iran, Published by Emirates Center for Strategic Studies and Research

22. Anthony H. Cordesman (1999) The Military Balance in the Middle East: An executive summary, Published by the Institute on Global Conflict and Cooperation, ISBN 0-934367-65-2

23. Abtahi, Ehsan (2005), "The Iran-Israel conflict from the annihilation of Israel to the denial of the Holocaust", Shargh Yearbook publication, Vol. II

24. Ahmadi, Kourosh (2002), "Jewish Power in America: From Myth to Reality", Rahbord Quarterly publication, Vol. 25.

25. Tobati, Hossein, ( 2003) "The danger of weapons of mass destruction of the Zionist regime from myth to reality, Published by Roznamah Quds.

26. Tavana, Kambiz (2004), In search of hidden uranium; Chronology of the events of the Iranian nuclear program ", Shargh newspaper, Nowruz special issue.

27. Shahid Sales, (2013), "Israel; Obstacle to Iran-West Nuclear Deal".

28. Adel Darwish and Gregory Alexander (1991), Unholy Babulon, The Secret Story of Saddam's War. London: Gollancz Ltd.

29. "Arrow Destroys Missile in Test". (November,1,1999), 2001, Online at:www.USIsrael.org/Jewishvirtuallibrary/

30. Bahour Sam. "The New United State of Israel." http://www.Counterpunch.org/ bahou0504.html/

31. Bard, Mitchell G. "Roots of the U.S.Israel Relationship." http://www.Jewishvirtuallibrary. org/

32. Bard, Mitchell G. (2007), Will Israel Survive? New York. PALGRAVE MACMILLANTM

33. Black Iam(1991). Israel's Secret Wars. Londonm Hamish Hamilton.

34. Cooley, John K (2005), An Alliance Against Babylon. Pluto Press.

35. Daniel Byman (2003), " Should Hezbollah Be Next?". Foreign Affairs,vol 82,No.6. (Nov/Dec).

36. Fuller Graham W. (1990), " The Middle East in US Soviet Relations". Middle East Journal, Vol.44, No3 (Summer).

37. Griffiths, Martin (2007), Fifty Key Thinkers in International Relation. London: Rutledge.

38. Journal of Palestine Studies (2003), No2, (Winter).

39. Mearsheimer, John J (2013), International Relations Theories. Ed(Third Edition) by Tim Dunne \& others. Oxford University Press

40. Parsi, Trita (2007), Treacherous Alliance the Secret Dealing of Israel, Iran, and The U.S. Yale University.

41. "Persian Gulf Oil and Gas Exports Sheet." Energy Information Administation, (2002), http://www.eia.doe.gov/emeu/cabs/Pgulf.html.

42. Segve Samuel (1988), The Iranian Traingle the Untold Story of Israel's Role in the Iran Contra Affair. The Free Press A Division of Macmilan, Inc New York.

43. Souva, Mark (2005), "Foreign Policy Determents: Comparing Realist and Domestic - Political Models of Foreign Policy". Conflict Management and Peace Science. 22: 149-163.

44. Thomas, Michael (2007), American Policy Toward Israel: The power and limits of belifs. Londn and New York, Routledge.

45. Waltz, Kenneth N. (1979), Theory of International Politics. Massachusetts: Addison Wesley publishing co.

46. Zohar, Sean (2014), An Exploration of Critical Discourse: The Iranian Nuclear Debate. Master's Research Paper.

47. Zuckerman Mortimer B (2015), Iran: The Last Lap. Available at: http://www.usnews. com/news/the-report/articles/2015/06/19/5-key-issues-in-nuclear-negotiations-with-iran

48. http://www.haaretz.com/middle-east-news/1.665736

49. http://www.bbc.com/persian/iran/2016/03/160327_me_inside_whitehouse_obama_iran

50. http://www.bbc.com/persian/world/2016/03/160322_u04_u01_us2016_canditates_iran 